\title{
O DISCURSO DA MÍDIA E A HOMOSSEXUALIDADE
}

\author{
Elso Soares Leite
}

\begin{abstract}
RESUMO
O presente artigo trata da homossexualidade nas instituiçóes militares e sua formação ideológica, através da análise dos enunciados da mídia e o que estas "dizem" sobre a homossexualidade, tratada como um "desvio" da heteronormatividade. A pesquisa se fundamenta nas contribuiçôes teóricas de Pêcheux (2008) sobre o discurso, bem como as teorias de Foucault (2009) sobre a sexualidade humana, entre outros.
\end{abstract}

PALAVRAS-CHAVE Mídia; Homossexualidade; Heteronormatividade.

\section{Introdução}

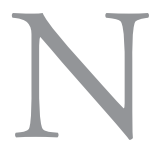

o final do século XIX, questôes relativas à sexualidade passaram a ocupar um espaço de grande importância nas discussóes e reflexóes acerca da constituição do sujeito moderno, proporcionando interesse crescente entre os estudiosos e teóricos de diversas áreas do conhecimento, principalmente a psicologia, a psicanálise e a sexologia. Nesse sentido Michel Foucault afirma:

Desde o século XVIII o sexo náo cessou de provocar uma espécie de erotismo discursivo generalizado. E tais discursos sobre o sexo não se multiplicaram fora do poder ou contra ele, porém lá onde ele se exercia e como meio para seu exercício; criaram-se em todo canto incitaçóes a falar; em toda parte, dispositivos para ouvir e registrar, procedimentos para observar, 
interrogar e formular. Desenfurnam-no e obrigam-no a uma existência discursiva. Do singular imperativo, que impóe a cada um fazer de sua sexualidade um discurso permanente, aos múltiplos mecanismos que, na ordem da economia, da pedagogia, da medicina e da justiça incitam, extraem, organizam e institucionalizam o discurso do sexo, foi imensa a prolixidade que nossa civilização exigiu e organizou (2009d, p. 39).

As discussões sobre o tema "sexualidade" foram aprofundadas, transformando-se no decorrer do século XX e ganhando posição de destaque no século XXI. Hoje, a sexualidade passou a ser vista e tratada de maneira recorrente em programas de televisão, novelas, no rádio e em sites de internet nos quais o privado é exposto e o cotidiano, por conseguinte, ganha destaque, enquanto a intimidade se torna pública e/ou política.

Foucault (2009e, p. 224) afirma que "foi o jornalismo - invenção fundamental do século XIX - que manifestou o caráter utópico de toda esta política do olhar", isto é, da política da vigilância permanente sobre os indivíduos através do controle de seus corpos, tornando-os "dóceis". Para Foucault (2009f), é dócil um corpo que pode ser submetido, utilizado, transformado, aperfeiçoado em função do poder. Para o autor, "esse poder que se exerce sobre o corpo é ininterrupto e, por isso, naturalizado, é internalizado pelo sujeito" (GREGOLIN, 2003, p. 99).

Nos últimos anos, a leitura de Michel Foucault por estudiosos de gênero e da sexualidade humana propiciou novas discussóes e debates substanciais sobre as relaçóes de poder. Para Foucault (2009d, p. 102), "a análise de uma formação de certo tipo de saber sobre o sexo, não em termos de repressão ou de lei, mas em termos de poder". Segundo Foucault (2009c, p. 86), no momento atual estamos vivendo o que se chamaria de ortopedia social. Trata-se, segundo ele, "de uma forma de poder, de um tipo de sociedade que classifico de sociedade disciplinar por oposição às sociedades propriamente penais que conhecíamos anteriormente. É a idade do controle social”. Ainda de acordo com Foucault (2009e, p. 233), "foi por volta de 1870 que os psiquiatras começaram a constituir a homossexualidade como objeto de análise médica: ponto de partida, certamente, de toda uma série de intervençóes e de controles novos", ou, conforme diz o autor: 
É o início tanto do internamento dos homossexuais nos asilos, quanto da determinação de curá-los. Antes eles eram percebidos como libertinos e às vezes como delinquentes (daí as condenações que podiam ser bastante severas - às vezes o fogo, ainda no século XVIII - mas que eram inevitavelmente raras). A partir de então, todos serão percebidos no interior de um parentesco global com os loucos, como doentes do instinto sexual. Mas, tomando ao pé da letra tais discursos e contornando-os, vemos aparecer respostas em forma de desafio: está certo, nós somos o que dizem, por natureza, perversão ou doença, como quiserem. E, se somos assim, sejamos assim e se vocês quiserem saber o que nós somos, nós mesmos diremos, melhor que vocês. Toda uma literatura da homossexualidade, muito diferente das narrativas libertinas, aparece no final do século XIX: veja Wilde ou Gide. É a inversão estratégica de uma "mesma" vontade de verdade (FOUCAULT, 2009e, p. 233-234, grifos do autor).

Desta feita, paralelamente ao crescente interesse do discurso médico sobre a homossexualidade, surgiram também manifestações homossexuais que visavam expor sua realidade, sua verdade, produzindo, como resistência, outros discursos sobre si mesmos, principalmente através da literatura. Foucault (2009d, p. 112) comenta:

[...] o aparecimento, no século XIX, na psiquiatria, na jurisprudência e na própria literatura, de toda uma série de discursos sobre as espécies e subespécies de homossexualidade, inversão, pederastia e "hemafroditismo psíquico" permitiu, certamente, um avanço bem marcado dos controles sociais nessa região de "perversidade"; mas, também, possibilitou a constituição de um discurso "de reação": a homossexualidade pôs-se a falar por si mesma, a reivindicar sua legitimidade ou sua "naturalidade" e muitas vezes dentro do vocabulário e com as categorias pelas quais era desqualificada do ponto de vista médico. 
$\mathrm{Na}$ compreensão de Foucault (2009d), ao invés do confinamento, das torturas físicas e psicológicas, das prisões dos homossexuais, como mecanismos de controle baseados em penalidades, aos quais se circunscreveram as sociedades do século XVIII, temos, na sociedade atual, mecanismos de controle social baseados nos sistemas de vigilância e de controle dos indivíduos. Estes indivíduos instituem suas práticas sociais e discursivas. Estas práticas discursivas são delimitadas pelo princípio da biopolítica, isto é, pelo princípio de uma gestão política global da vida dos indivíduos (REVEL, 2005, p. 55).

Assim, os discursos que a mídia produz sobre determinado tema, como a homossexualidade, são discursos que só se tornam possíveis de acordo com suas condições de produção. Os discursos que a mídia produz se dão de acordo com os mecanismos de controle social, isto é, os discursos se realizam por meio de certas regras e normas, próprias da ordem do discurso. E é por esse viés da ordem do discurso que Foucault supóe que:

[...] em toda sociedade a produção do discurso é ao mesmo tempo controlada, selecionada, organizada e redistribuída por certo número de procedimentos que têm por função conjurar seus poderes e perigos, dominar seus acontecimentos aleatórios, esquivar sua pesada e terrível materialidade (2009a, p. 9).

Existem mecanismos ou procedimentos que determinam de que maneira o discurso pode se constituir em condiçôes dadas. Por isso, Foucault (2009a) destaca a interdição como um dos mecanismos de controle discursivos mais utilizados na sociedade disciplinar atual, além da exclusão. Segundo o autor, a interdição é muito utilizada como procedimento de controle de discursos sobre o sexo ou sexualidade humana, principalmente sobre a homossexualidade. Em relação à interdição, Foucault (2009a) afirma: "sabe-se bem que não se tem o direito de dizer tudo, que não se pode falar de tudo em qualquer circunstância, que qualquer um, enfim, não pode falar de qualquer coisa" (FOUCAULT, 2009a, p. 9).

É a interdição que nos explica o porquê de muitos discursos sobre a homossexualidade, em diferentes momentos da história, terem sido discursos marcados pelo silenciamento. Para Eni Orlandi (2007c), o silenciamento é, também, uma forma de significar, pois o silêncio em deteminado lugar e 
momento socio-histórico produz sentidos. Assim, o sentido do silenciamento do discurso homossexual foi constituído pela censura, pela interdição, ou seja, através do silenciamento foi negado aos homossexuais o direito de "falar" sobre si mesmos, isto é, de significar-se e fazer-se significar por meio de discursos que pudessem revelar sua verdade sexual, sua identidade e seus desejos.

Segundo Alexandre Sebastiāo Ferrari Soares (2006), durante muitos anos ao homossexual foi imposto o silêncio, mas um silêncio que não o colocava apenas à margem da sociedade heterossexual, mas que o constituía como criminoso-pecador-doente, a partir de discursos que podiam lhe dar sentido: jurídico-religioso-médico. Nesse sentido, podemos dizer que sempre foi difícil, na história da humanidade, falar sobre a homossexualidade a partir de outros sentidos, senão a partir daqueles relacionados à ideia de: anormalidade, doença, pecado, crime. Com efeito, tais sentidos relacionados à homossexualidade se tornaram de tal forma familiares nos dizeres proferidos em diferentes lugares e momentos socio-históricos, que não deixaram "espaço" para se pensar sobre isso além daqueles sentidos "cristalizados" na memória social.

Segundo Luiz Mott (2006, p. 01), nestes últimos quatro mil anos de história humana, "o ocidente repetiu que o amor e o erotismo entre pessoas do mesmo sexo eram o mais torpe, sujo e desonesto pecado, e que por causa dele Deus castigava a humanidade com pestes, inundaçóes, terremotos". No momento atual, notamos que o discurso sobre a homossexualidade como sendo uma "doença", "pecado" ou mesmo "aberração" continua se perpetuando nos discursos das pessoas em geral, sobretudo quando são incitadas a "falarem" sobre isso, no momento em que a mídia póe o tema "homossexualidade" na ordem do dia, por meio de seus textos jornalísticos.

Assim, ao realizar as leituras sobre gênero e sexualidade, sobretudo a homossexualidade a partir das contribuiçóes teóricas de Foucault e de outros estudiosos da sexualidade humana, surgiu a ideia de trabalhar com o tema "homossexualidade", no contexto das instituiçôes militares, investigando de que maneira a mídia impressa e eletrônica (internet) a tem representado ou noticiado. Para tanto, investigamos, por meio dos enunciados provenientes das matérias jornalísticas impressas ou eletrônicas, o modo pelo qual a mídia veicula discursos sobre a homossexualidade no interior das instituiçóes militares. Assim, o objetivo de nosso trabalho é analisar aspectos do funcionamento do discurso da mídia sobre a homossexualidade nas organizações militares. 
Desse modo, a nossa proposta é compreender quais sentidos sobre a homossexualidade continuam ecoando na mídia imprensa brasileira por meio de textos-notícia sobre a homossexualidade no interior das instituições militares. Em nossa compreensão, as instituiçóes militares, consideradas por Althusser (1969) como Aparelhos Repressivos do Estado, podem tratar as questóes de gênero (social), principalmente a homossexualidade, como "tabu", evitando "falar sobre o assunto", ou conforme comenta Napoleão Dagnese (2000, p. 33):

Previsto como crime contra os costumes, o art. 235 do Código Penal Militar (CPM) brasileiro traz a prática do homossexualismo, ocorrendo em local sob a administração militar. Trata-se de crime de mão própria, estando, em princípio, afastada a hipótese do concurso de agentes, tendo o agente previamente definido o delito, o que o agrava. [...] Trata-se de tabu a homossexualidade no ambiente militar, onde se evita tocar no assunto, [...], na melhor prática do finja que não és, finjo que não sei (grifos do autor).

Sendo assim, presume-se que deve ser muito "complicado" para os policiais militares discutirem e se posicionarem a respeito dessa temática, uma vez que os sentidos de suas palavras são marcados pela ordem discursiva institucional militar. Ou seja, supomos que os sentidos das palavras dos militares são determinados pela formação ideológica institucional, isto é, os sentidos das palavras dos militares se definem por meio do que a instituição militar autoriza ou não ser dito sobre a homossexualidade.

\section{O discurso da mídia: o encontro entre a estrutura e acontecimento}

O discurso serve para comunicar e para náo-comunicar, pois é a um só tempo, um objeto simbólico e político. Simbólico no sentido de que náo é uma etiqueta que representa um determinado objeto cuja ordenação, categorização, interpretação preexiste à significação; e político no sentido de que é uma luta de poder, "afrontamento, relação de força, situação estratégica". (BARONAS, 2003, p. 84) 
Pêcheux (2008) discute em termos metodológicos como a AD analisa o discurso a partir de seu funcionamento, ou seja, como os sentidos são construídos no/pelo discurso através da relação entre suas dimensôes constituintes: a dimensão da língua - como estrutura; e a dimensão da história - como acontecimento. Ele toma como ponto de partida o enunciado on a gagné ["ganhamos"], da TV de Paris, no dia 10 de maio de 1981, quando François Mitterrand venceu as eleições para a presidência na França.

Pêcheux (2008) observou que o sentido evidenciado no funcionamento do discurso político em torno da vitória de Mitterand náo se dava apenas pelo viés de sua materialidade linguística, constituída pelo enunciado on a gagné. Se assim o fosse, todos os franceses interpretariam o termo "ganhamos" a partir do sentido comumente atribuído pelos torcedores nos estádios esportivos, quando há vitória do time pelo qual torcem. Assim, o sentido logicamente estabilizado (isto é, o sentido de vitória coletiva dos torcedores esportivos) tinha a pretensão de fazer da vitória eleitoral de Miterrand a vitória real e totalizante de todos os franceses.

No entanto, Pêcheux (2008) observa que, no momento em que a mídia proferiu o enunciado on a gagné, houve um confronto discursivo, pois nem todos os franceses interpretaram a vitória de Miterrand como uma vitória coletiva. Desse modo, naquela conjuntura socio-política da França de 1981, não houve apenas um sentido evidenciado no funcionamento do discurso midiático, porque não havia um sujeito que "falava" nesse discurso como se fosse um "porta-voz" de todos os franceses. Ao contrário, foram evidenciados vários sujeitos no funcionamento do discurso midiático, marcados por suas diferenças socio-ideológicas, por seus diferentes discursos e sentidos, mostrados a partir de seus diferentes "gestos de interpretaçáo" diante daquele acontecimento histórico.

Desse modo, Michel Pêcheux (2008) postula que não há uma só palavra original, de sentido único. Para o autor, os sentidos são sempre evidenciados pela fala do outro que os atravessa e os constitui, no cruzamento entre uma atualidade e uma memória. Nesse sentido,

[...] todo enunciado é intrinsecamente suscetível de tornar-se outro, diferente de si mesmo, se deslocar discursivamente de seu sentido para derivar para um outro (a não ser que a proibição 
da interpretação própria ao logicamente estável se exerça sobre ele explicitamente). Todo enunciado, toda sequência de enunciados é, pois, linguisticamente descritível como uma série (léxico-sintaticamente determinada) de pontos de deriva possíveis, oferecendo lugar a interpretação (PÊCHEUX, 2008, p. 53).

Segundo Maria do Rosário Gregolin (2003, p. 97), a criação dessa ilusão de 'unidade' do sentido é um recurso discursivo que fica evidente nos textos da mídia, desempenhando o papel de mediação entre seus leitores e a realidade. $\mathrm{Na}$ visão da autora, “[...] como construtora de imagens simbólicas - a mídia participa ativamente, na sociedade atual, da construção do imaginário, no interior do qual os indivíduos percebem-se em relação a si mesmos e em relação ao outros" (GREGOLIN, 2003, p. 97).

No entender de Bronislaw Baczko, o imaginário social:

[...] se expressa por ideologias e utopias, que se materializam em símbolos, alegorias, rituais e mitos. Através dessas textualizações, erigem-se visōes de mundo, modelam-se condutas e estilos de vida, em movimentos contínuos ou descontínuos de preservação da ordem vigente ou de introdução de mudanças. Para o autor, a imaginaçáo social, além de fator regulador e estabilizador, também é a faculdade que permite que os modos de sociabilidade existentes não sejam considerados definitivos e como os únicos possíveis, e que possam ser concebidos outros modelos e outras fórmulas (1985, p. 403).

A mídia trabalha com discursos que possam produzir suas "verdades" no imaginário social. Assim, os fatos imediatos do cotidiano, transformados em notícia, são compreendidos como "naturais", e não socialmente construídos por meio de múltiplos discursos. O discurso jornalístico "hierarquiza os sentidos e os valores [...] preconiza condutas [...] os modos de falar e separa o que é dizível e o que é indizível” (GOMES, 2003, p. 10).

No funcionamento do discurso da mídia, há sentidos que são censurados, silenciados; há outros que, pela força da repetição, tornam-se naturali- 
zados, mas, ainda que legitimados, estão sujeitos a deslizamentos, por conta da influência da história e do jogo das relações ideológicas entre sujeitos. É a ideologia que regula os sentidos possíveis para o sujeito em determinadas condiçôes de produção discursivas.

Por exemplo, no enunciado do Jornal Correio da Babia de 17 de junho de 2008: "Polícia Militar da Bahia não está livre dos gays", há o discurso preconceituoso sustentado pelos discursos cristão e jurídico, cujos sentidos apontam a homossexualidade como um desvio de conduta moral ou como uma marginalidade. Assim, os homossexuais não podem fazer parte de uma instituição militar que preza pela ordem e segurança da sociedade, já que são "portadores" de uma sexualidade "marginalizada", considerada um desvio de conduta. Nesse sentido, o discurso jornalístico pode construir sentidos sobre a homossexualidade nas instituiçóes militares, retratando-a de forma estigmatizada, o que intensifica o processo de marginalização dos homossexuais na sociedade.

\section{A ordem do discurso na mídia}

Pedro Navarro-Barbosa (2003, p. 113) afirma: "no discurso jornalístico, o lugar midiático articula-se também com o saber e o poder. $\mathrm{O}$ jornalista não pode falar como quiser, pois tem de submeter-se a certas regras internas e externas da instituição midiática”. Por esse viés, o autor acrescenta:

Quanto ao poder, a relação entre a chamada grande imprensa, as elites e os detentores do poder aparecem na forma [...] de "denuncismo": o uso da imprensa para legitimar as atitudes de uma autoridade política ou conferir tratamento pejorativo aos fatos a ela relacionados. A mídia cria, portanto, mocinhos e bandidos, heróis e derrotados (NAVARRO, 2003, p. 113).

A homossexualidade na mídia foi, desde sempre, retratada de forma estigmatizada e inferiorizada, principalmente em programas humorísticos. Segundo Didier Eribon (2008),

1 Ver anexo I. 
a homossexualidade há tempos vem dando lugar a uma proliferação de imagens que desvalorizam, degradam principalmente na caricatura (mas também no cinema e na televisão, que, em geral, só fazem fornecer, com novos meios, imagens bem próximas da tradição caricaturista). [...] A caricatura homófoba [...] é uma "difamação"; ela faz "alusão" à injúria, inscreve-se no horizonte da injúria e apela para os esquemas mentais que permitem fazer rir a propósito dos homossexuais. Exprime a inferioridade atribuída à homossexualidade na sociedade e perpetua as estruturas mentais que fundam essa inferioridade. Faz "alusão" à condenação imemorial da homossexualidade e chama, por conseguinte, a atenção de toda a violência simbólica, cultural, política e jurídica de que os gays são objeto (2008, p. 90-91, grifos do autor).

No entender de Foucault (2009a), o discurso expressa um saber, pelo qual exerce um poder. Para o autor, há em todo discurso uma "vontade de verdade" que, ao trazer em si a oposição entre o verdadeiro e o falso, classifica algo como verdadeiro. Essa oposição entre o verdadeiro e o falso é o que sustenta o sistema de exclusão de que a mídia se utiliza em suas produçóes jornalísticas.

O discurso da mídia é um produto que só se torna possível por meio de condiçóes e procedimentos que ela mesma estabelece, baseada em sua própria "ordem do discurso". Assim, a mídia institui seu discurso como verdadeiro. É nessa perspectiva que Foucault (2009b, p. 205) afirma: “[...] não há saber sem uma prática discursiva definida, e toda prática discursiva pode definir-se pelo saber que ela forma”.

Para Navarro-Barbosa (2010, p. 84), “a mídia é um campo institucional em que o sujeito que nela fala é, ao mesmo tempo, aquele que pode dizer a verdade dos fatos - pelo saber que detém sobre eles - e aquele que pode produzir os fatos na sua verdade e submetê-los à realidade - pelo poder que exerce na sociedade". Assim, a mídia funciona "como um jogo de legitimação e controle". Ciro Marcondes Filho (1989) argumenta:

[...] na produção da notícia entram em cena dois sujeitos: o jornalista, cuja tarefa é selecionar da realidade o fato que lhe 
interessa para transformá-lo em acontecimento, e o editor, que tem o poder de decidir qual será o enfoque dado à matéria, a quantidade de linhas destinadas ao seu desenvolvimento, o tamanho e os tipos do título e a colocação na página. Ao editor cabe, portanto, a missão de definir a política de como o fato deverá repercutir na sociedade, de como "um acontecimento pequeno pode fazer um escândalo, de como suprimir naturalmente a divulgaçáo de ocorrências, como se elas simplesmente não tivessem realmente existido" (1989, p. 50).

Um exemplo disso é a matéria jornalística divulgada pela Folha online cujo título é: "Revista da Globo evita capa com beijo entre sargentos gays do Exército"2. Em linhas gerais, a Revista Época (número 524, de junho de 2008) decide qual imagem de capa irá publicar. Por esse controle, a revista determinou a escolha da imagem "sem o beijo entre os militares" como a opção mais "adequada".

Segundo Foucault (2009a), a "interdição" é o procedimento de exclusão mais utilizado na sociedade contemporânea, que se caracteriza pelo controle e pela vigilância dos "fazeres/dizeres" dos indivíduos. A "interdição", como um procedimento de controle dos discursos da mídia, funciona como um mecanismo de controle e de vigilância social, determinado pela sociedade disciplinar, a qual impóe aos indivíduos suas leis, suas regras, seus valores, permeados por questóes de ordem sociopolítica, econômica e ideológica.

Segundo Patrícia Monteiro Cruz (2009), a imagem, ao lado da notícia, cria efeitos de sentido e opera na produção de verdades cristalizadas socialmente. Assim, para que possamos empreender uma análise do discurso da mídia é necessário perceber as diferentes linguagens que povoam os enunciados jornalísticos: a verbal e a não-verbal.

\section{A homossexualidade na mídia: uma discussão histórico-discursiva}

A visibilidade e a repercussáo em torno da homossexualidade se devem muito ao trabalho da mídia ${ }^{3}$. Nesse sentido, James Green e Ronald Polito

2 Ver anexo II.

3 Segundo Rodinesco e PLon (1998, p. 350), “o termo homossexualidade derivado do grego 
(2006) afirmam: “[...] os jornais e revistas são fundamentais para avaliarmos como lentamente vai se tornando pública a questão da homossexualidade: de 'criminoso', ou 'doente', a militante do movimento gay, muita coisa aconteceu, muita história se passou” (2006, p. 18).

Para os autores, os relatos acerca da homossexualidade na mídia foram construídos em torno de estigmas marcados historicamente. Segundo eles, os homossexuais noticiados pela mídia, entre as décadas de 1960 a 1970, eram relatados nos cadernos policiais ou nas matérias sobre o carnaval. Na compreensão dos autores, o discurso que a mídia produzia em torno da homossexualidade recebia contorno identitário de uma sexualidade marcada pela marginalidade, pelo ridículo e pelo riso. Hiro Okita (2007) comenta:

Na grande imprensa, a questão da homossexualidade está sempre ligada à criminalidade. Os jornais dedicados ao noticiário policial, principalmente, colocam-se claramente anti-homossexuais, promovendo os crimes praticados por eles e usando uma linguagem desmoralizante e agressiva ao se referir a estes casos. Jamais se lê uma manchete: "Heterossexual mata amante". Poucos noticiam crimes praticados contra os homossexuais, que são agredidos nas ruas, moral e fisicamente, fazendo aumentar mais ainda o desinteresse da sociedade, a qual além de não dar a mínima atenção para estes fatos, recebe com maior simpatia e humor essas agressôes (OKITA, 2007, p. 85-86)

(homos: igual) e criado por volta de 1860 pelo médico húngaro Karoly Maria Benkert para designar todas as formas de amor carnal entre pessoas biologicamente pertencentes ao mesmo sexo. Entre 1870 e 1910, o termo homossexualidade se impôs progressivamente nessa acepção em todos países ocidentais, substituindo assim as antigas denominaçóes que caracterizavam essa forma de amor conforme as épocas e as culturas (inversão, uranismo, safismo, lesbianismo etc). Definiu-se por oposiçáo à palavra heterossexualidade (do grego heteros: diferentes), cunhada por volta de 1880 que abrangia todas as formas de amor carnal entre pessoas de sexos biologicamente diferentes". Importante dizer que nessa época era comum usar o termo homossexualismo no lugar de homossexualidade, pois nessa época as pessoas generalizaram os nomes de doenças ou fenômenos ligados à ciência biológica, médica e psiquiátrica com o uso do sufixo "-ismo", como acontece com lesbianismo, safismo etc. 
Na compreensão de Okita (2007, p. 86), a visão cômica dos homossexuais é promovida pelos "fabricantes de cultura", seja no cinema, no teatro ou na TV. Para o autor, "[...] ele ou ela é sempre um sujeito estereotipado, cheio de trejeitos e melindres, sem outros sentimentos que não seja sexo. É visto como algo que provoca risos e não uma pessoa como todas as outras, como um oprimido igual a todos". (OKITA, 2007, p. 86).

A título de ilustração, mencionamos os enunciados-títulos de duas capas do jornal O Lampião na Esquina (ver figura 1 e figura 2) que circulou na sociedade carioca nos anos 1970: "As relações perigosas" e "Carnaval das bichas é o maior do mundo".

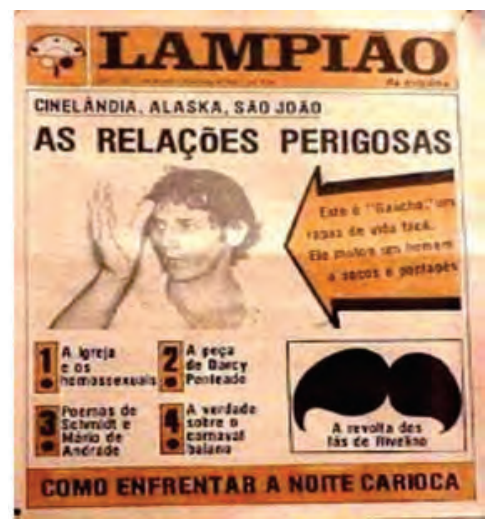

Figura 1- Lampião. Ed.01, maio/junho de 1978

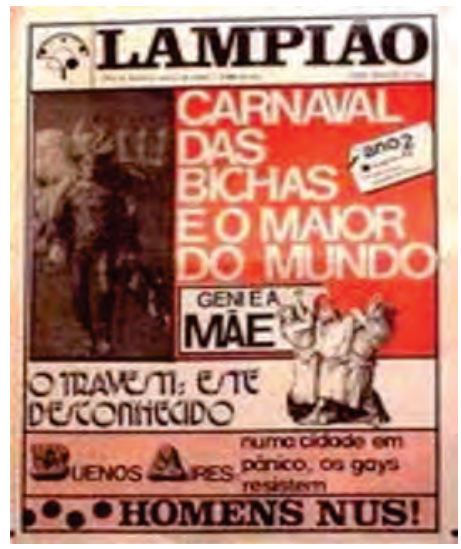

Figura 2- Lampião. Ed.22, março de 1980. 
No enunciado de capa do jornal (ver figura 1), "As relações perigosas", há o discurso preconceituoso, retratando as relações homossexuais como relaçóes "perigosas". As relações homossexuais eram relaçôes "marginalizadas" no discurso da sociedade carioca da época. Para a mídia da época, era comum falar da homossexualidade, relacionando-a a temas ligados à violência e à marginalidade. $\mathrm{O}$ discurso materializado naquele enunciado (da figura 1) evidencia o sentido da homossexualidade como uma prática sexual "marginal", isto é, uma prática que não podia ser exposta. Caso fosse exposta, a homossexualidade deveria se referir a fatos que estivessem relacionados à violência física, a assassinatos ou a desordem social. A mídia daquela época também noticiava a homossexualidade, retratando-a em torno de temas que levavam ao riso, ao lúdico, ao carnaval, conforme vemos no enunciado do Jornal Lampião (ver figura 2): "Carnaval das bichas é o maior do mundo".

Entretanto, segundo Green e Polito (2006), foi em 1963, no Rio de Janeiro, que foi editada uma das primeiras publicaçóes para gays no Brasil: o jornal "O Snob". Esse jornal era distribuído gratuitamente na Cinelândia e em Copacabana e circulou na sociedade carioca de 1963 a 1969, quando foi proibido pelo regime militar ditatorial. Segundo os autores, foi somente nos anos de 1970 que os homossexuais foram noticiados em colunas jornalísticas destinadas a eles. Nesse sentido, os autores afirmam:

[...] o ano de 1977 foi marcado por uma verdadeira explosão discursiva em torno da homossexualidade no Brasil. Inúmeras matérias em jornais e revistas [...] atestam o fato de que gays tinham se tornado assunto público de grande relevância (GREEN; POLITO, 2006, p. 178).

Para os autores, com o fim da ditadura militar a mídia teve maior abertura política para falar sobre a homossexualidade, principalmente com o advento do jornal O Lampião na Esquina. Esse jornal representou um marco brasileiro de abertura para os movimentos sociais. $\mathrm{O}$ movimento de afirmação homossexual foi reconhecido nacionalmente, junto com outros movimentos sociais, como o movimento negro, o movimento feminista, o movimento indígena e os movimentos ecológicos. A título de exemplo, mencionamos o enunciado de capa do Jornal Lampião "Libertários" (ver figura 3), cuja edição tratava a homossexualidade no bojo das discussóes de outros movimentos libertários. 


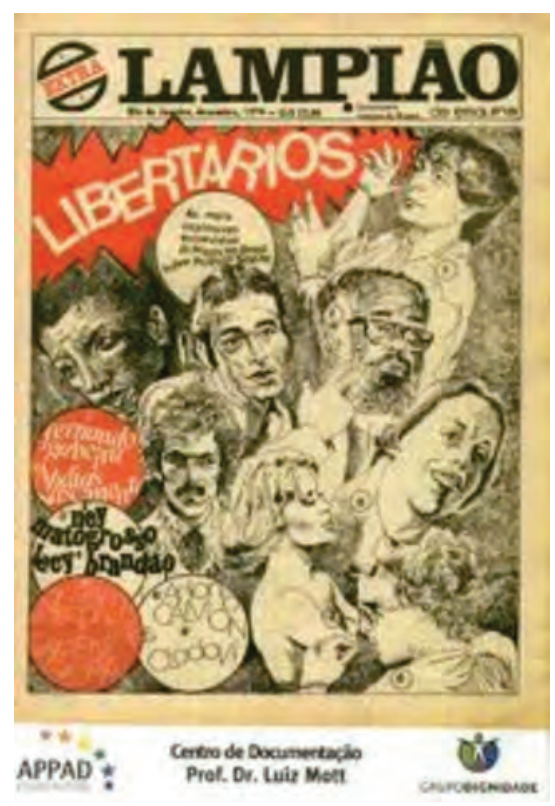

Figura 3- Lampião. Ed. extra 01, dezembro de 1979.

Segundo Green e Polito (2006), o jornal "O Lampião na Esquina" sofreu inquérito policial e, posteriormente, foi extinto porque representava uma ameaça "à moral e os bons costumes". Para Okita,

na Constituição Brasileira e no Código Penal não existe nenhum artigo que considere crime a prática ou a divulgação da homossexualidade, portanto, a opressão e discriminação, geralmente, tomam formas muito mais discretas. Mesmo assim, existem várias leis para discriminar e reprimir a homossexualidade. [...] A Lei de Imprensa dá poderes ao governo de censurar ou fechar jornais sob a justificativa de divulgar matérias atentatórias à 'moral e aos bons costumes', um critério completamente vago e arbitrário $(2007$, p. 81$)$.

Já nos anos 1980, as manifestaçóes e reivindicações homossexuais se intensificaram na mídia, com o advento da Síndrome da Imunodeficiência Adquirida (AIDS). Como os primeiros sintomas da doença foram constatados 
em homossexuais, a mídia passou a divulgar a imagem do homossexual como "grupo de risco". Na visão de Simôes (2006), o discurso sobre a homossexualidade como doença, instituído pelo discurso médico-psiquiátrico na última década do século XIX, é retomado na mídia, agora reforçado pela AIDS.

Por isso que Orlandi (2007a, p. 39) afirma: "não há discurso que não se relacione a outros. Os sentidos resultam de relaçóes: um discurso aponta para outros que o sustentam, assim como para dizeres futuros”. Segundo Soares (2006), o discurso médico constituído pelo sentido da homossexualidade ligada à AIDS estava relacionado, paralelamente, ao discurso religioso cujo sentido reforçava a ideia de que as práticas homossexuais eram práticas promíscuas. Nesse sentido, o homossexual é aquele indivíduo que pratica sexo de forma exacerbada e com um número variável e elevado de parceiros. A homossexualidade associada à promiscuidade, sustentada pelos discursos médico e religioso, seria responsável pelo aumento de chances de contração da AIDS. Assim, o discurso religioso-cristão tinha como efeito de sentido a ideia de "conversão sexual", ou seja, ao se redimir da condição de homossexual, um indivíduo poderia evitar a doença, considerada um castigo divino à sodomia.

Nos anos 1990, a Organização Mundial de Saúde (OMS) ${ }^{4}$ anunciou que a homossexualidade não deveria mais ser considerada como doença ou patologia. Isso levou os homossexuais a intensificar suas manifestações em favor dos seus direitos como indivíduos normais. Segundo Elisabeth Rodinesco e Michel Plon (1998, p. 352), a American Psychiatric Associaton (APA) "riscou a homossexualidade da lista das doenças mentais, através de um plebiscito, por conta da pressão dos 'movimentos de liberação sexual' ocorrido em 1974". Segundo os autores, esse caso provocou um escândalo, pois

[...] sinalizou que a comunidade psiquiátrica norte-americana, na impossibilidade de definir cientificamente a natureza da

4 A 10a edição da Classificação Internacional de Doenças - CID-10 (OMS, 1993) e a quarta edição do Manual Diagnóstico e Estatístico de Transtornos Mentais - DSM-IV (APA, 1995) excluíram a homossexualidade da classificação "doença". No Brasil, o Conselho Federal de Psicologia redigiu a resolução 001/1999, estabelecendo normas de atuação dos psicólogos com relação à orientação sexual das pessoas. $\mathrm{O}$ texto considera a homossexualidade como algo não patológico e proíbe que os psicólogos considerem seus pacientes como portadores de doenças (CEP, 1999). 
homossexualidade, havia cedido à pressão da opinião pública, fazendo seus membros votarem sobre um problema cuja solução não dependia de um processo eleitoral (RODINESCO; PLON, 1998, p. 352).

A posição da Associação Americana de Psiquiatria despertou interesse de pessoas influentes, como: políticos, intelectuais, artistas etc., de diversas partes do mundo, que se organizaram em ONGs e passaram a realizar várias manifestaçóes de afirmação homossexual.

Segundo João Silvério Trevisan (2004, p. 204-205), todos esses acontecimentos em torno da homossexualidade, nos Estados Unidos e algumas partes do mundo, ajudaram a consolidar a abertura de açóes políticas mundiais que legitimaram a diversidade sexual. Segundo o autor, as minorias sexuais passaram a se expressar de forma mais organizada, favorecendo o crescimento das Paradas anuais do Movimento Brasileiro de Gays, Lésbicas, Bissexuais e Transgêneros (GLBT). ${ }^{5}$ Segundo Green e Polito (2006), essas Paradas da diversidade sexual, realizadas no Brasil e em muitos outros países, deram aos homossexuais o direito de lutarem abertamente por seus direitos políticos e sociais, como a legalização do casamento entre indivíduos do mesmo sexo, a adoção de crianças por pais homossexuais, a assistência judiciária para casos de violência contra os gays e a concessão de cirurgia para troca de sexo.

Como podemos perceber, o discurso da mídia evidencia e, possivelmente, continuará evidenciando, em seu funcionamento, sentidos que revelam a homossexualidade de forma estigmatizada, em diferentes momentos históricos. Esses sentidos, segundo Jean-Jacques Courtine (2009, p. 90), se constituem na articulação de um discurso a outros discursos, através da memória discursiva. Assim, os sentidos que evidenciam a homossexualidade como: "marginalidade", "promiscuidade", "anormalidade", "doença”, "pecado" são retomados, no funcionamento do discurso, na instância entre a constituição (interdiscurso) e a formulação (intradiscurso) do que se "diz" sobre isso.

5 Hoje nos movimentos da diversidade sexual se tem usado a sigla GLBT por conta do movimento das lésbicas que protestaram contra a posição secundária da mulher, posição que representa um reforço do preconceito às mulheres, sobretudo às feministas lésbicas. 


\section{Conclusão}

Vimos, em nossa análise, que a questão da visibilidade da homossexualidade no ambiente militar é vista como uma "afronta" para os militares heterossexuais, bem como para as instituiçóes militares de forma geral. Assim, o discurso da mídia também nos mostrou a homossexualidade como algo que deve ser confiscado, a todo o momento, no contexto militar. Observamos, em alguns enunciados analisados, que muitos homossexuais militares são penalizados por "assumirem-se" homossexuais. Dentre as penalidades relatadas, evidenciamos: perseguições, retaliações, ameaças, rechaços e deserçóes. Por isso, a boa parte dos homossexuais militares "prefere" manter sua sexualidade nos "armários" das corporações.

Notamos que a mídia constrói e reforça representaçôes do discurso social hegemônico da heteronormatividade, cujos efeitos de sentido revelam a homossexualidade de forma estigmatizada, reforçando a segregação e o preconceito não somente no contexto militar, mas também no contexto social em geral. Nesse sentido, podemos afirmar que a heteronormatividade, por meio da mídia, agencia o que deve ser mostrado e consumido pela sociedade através das representaçóes de linguagem.

Desse modo, observamos que a mídia produz e reafirma discursos heteronormativos que são "consumidos" sem nenhuma problematização ou questionamentos por parte dos sujeitos, levando-os a uma consciência "naturalizada" da realidade. Esse fato não interfere apenas na conduta e nos padróes de vida dos indivíduos considerados normais no seio social, mas também apresenta incidência nas relações e na visão de que os ditos "anormais" têm de si próprios e dos modos de subjetivação do qual fazem parte.

\section{Referências}

BACZKO, B. Imaginação social. In: Enciclopédia Einaudi. Lisboa: Imprensa Nacional/Casa da Moeda; Editora Portuguesa, 1985.

BARONAS, R. L. A língua nas malhas do poder. In: . Discurso e mídia:

a cultura do espetáculo/ [organizado por] Maria do Rosário Gregolin. São Carlos: Claraluz, 2003.

COURTINE, J.J. Análise do discurso político. O discurso comunista endereçado aos cristãos. São Carlos: EDUFSCAR, 2009. 
DAGNESE, N. Cidadania no armário - Uma abordagem sócio-jurídica acerca da homossexualidade -/ Napoleão Dagnese. - São Paulo: Ltr, 2000.

ERIBON, D. Reflexóes sobre a questão gay / Didier Eribon; tradução Procopio Abreu; editor José Nazar. - Rio de Janeiro: Companhia de Freud, 2008.

FOUCAULT, M. A ordem do discurso; aula inaugural no Collège de France, pronunciada em 2 de dezembro de 1970; tradução Laura Fraga de Almeida Sampaio. São Paulo: Ediçóes Loyola, 18 ed, 2009a.

. Arqueologia do saber. Rio de Janeiro: Forense Universitária, $2009 \mathrm{~b}$.

A verdade e as formas juridicas/Michel Foucault, (tradução Roberto Cabral de Melo Machado e Eduardo Jardim Morais, supervisáo final do texto Léa Porto de Abreu Novaes... et al.J. - Rio de janeiro: NAU Editora. 3a ed. 5a reimpressão, 2009c.

- História da sexualidade I: A vontade de saber. Tradução de Maria Tereza da Costa Alburqueque e J. A. Guilhon Alburqueque. Rio de Janeiro, Ediçóes Graal. 19a ed, 2009d.

. Microfísica do poder/Michel Foucault; organização e tradução de Roberto Machado. Rio de Janeiro: Ediçóes Graal. 27ª reimpressão, 2009e.

GOMES, M. R. Poder no jornalismo: discorrer, disciplinar, controlar. São Paulo: Hacker Editores, Edusp, 2003.

GREEN, J. N.; POLITO, R. Frescos trópicos: fontes sobre homossexualidade masculina no Brasil (1870-1980). Rio de Janeiro: José Olímpio, 2006. (Baú de Histórias)

GREGOLIN, R. M, do. "O acontecimento discursivo na mídia: metáfora de uma breve história do tempo". In: Discurso e midia: a cultura do espetáculo/ [organizado por] Maria do Rosário Gregolin. São Carlos: Claraluz, 2003.

MARCONDES FILHO, C. O capital da notícia: jornalismo como produção social da segunda natureza. 2a Ed. São Paulo: Ática, 1989.

MOTT, L. Homo-afetividade e direitos humanos. Revista Estudos Feministas. vol.14 no.2. Florianópolis. 2006.

NAVARRO-BARBOSA, P. O papel da imagem e da memória na escrita jornalística da história do tempo presente. In: - Discurso e mídia: a cultura do espetáculo/ [organizado por] Maria do Rosário Gregolin. São Carlos: Claraluz, 2003. 
ORLANDI, E. P. Análise de discurso: Princípios \& Procedimentos. Campinas SP: Pontes, 2007a.

OKITA, H. Homossexualidade: da opressão à libertação. São Paulo: Sundermann, 2007.

PÊCHEUX, M. O discurso: estrutura ou acontecimento. Trad: Eni P. Orlandi. 5a Ed.: Campinas, SP, Pontes Editores, 2008.

REVEL, J. Michel Foucault: conceitos essenciais/Judith Revel; Trad. Maria do Rosário Gregolin, Nilton Milanez, Carlos Piovesani. São Carlos: Claraluz, 2005.

ROUDINESCO, E.; PLON, M. Dicionário de psicanálisel Elisabeth Roudinesco, Michel Plon; tradução Vera Ribeiro, Lucy Magalhães; supervisão da edição brasileira Marco Antonio Coutinho Jorge. Rio de janeiro: Jorge Zahar 1998.

TREVISAN, J. S. Devassos no paraiso: a homossexualidade no Brasil, da colônia à atualidade. Rio de Janeiro: Record, 2004.

\title{
THE MEDIA DISCOURSE AND THE HOMOSEXUALITY
}

\begin{abstract}
This article deals with homosexuality in military institutions and their ideological formation, through the analysis of the statements of the media and what they "say" about homosexuality, treated as a "deviation" of heteronormativity. The research is based on the theoretical contributions of Pecheux (2008) on the discourse as well as the theories of Foucault (2009) on human sexuality, among others.
\end{abstract}

KEY-WORDS: Media; Homosexuality; Heteronormativity.

Recebido em: 30/08/2013

Aprovado em: 20/12/2013 


\section{ANEXO I}

\section{A Polícia Militar da Bahia não está livre dos gays}

Jean Wyllys*

Não pretendo transformar este espaço numa tribuna de defesa dos direitos da comunidade LBGT, mas, se o país inteiro está discutindo o caso do tenente da PM da Bahia Ícaro Ceita do Nascimento, suposta vítima de homofobia por parte da PM, por que me calar? A homofobia é aquele ódio que a maioria dos heterossexuais (mas, também, alguns homossexuais) nutre por gays e lésbicas e que não só violenta simbólica e realmente a comunidade gay, como a impede de exercer direitos fundamentais e civis.

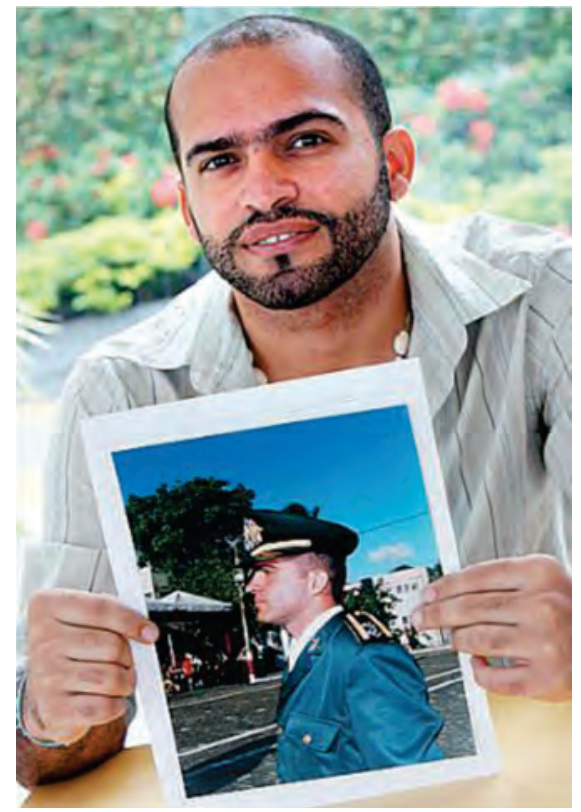

\section{Ícaro Ceita do Nascimento, suposta vítima de homofobia}

Não se trata de defender o tenente Ícaro das acusaçôes de caloteiro e desequilibrado feitas pelo coronel Carlos Maurício, até porque não conheço a vida do tenente nem seu caráter para defendê-lo. Trata-se, antes, de uma análise das falas do coronel Carlos Maurício bem como do parecer sobre o caso do 
promotor militar Luiz Augusto de Santana, para, a partir daí, defender todos os homossexuais da PM, assumidos ou não, que ameaçados e/ou melindrados pela homofobia de seus superiores hierárquicos.

A indigência intelectual e os preconceitos do promotor me espantam. Ele foi capaz de escrever algo que provocaria riso se não materializasse preconceitos em relação à convivência entre homens homossexuais e heterossexuais: 'Dormimos em alojamentos coletivos, comemos em ranchos coletivos, tomamos banho de forma coletiva, e não sei quais reações teria um homossexual no meio de pessoas do mesmo sexo despidas'. Dá para considerar alguém que escreve uma coisa dessas um promotor de justiça de fato? O texto expressa uma fantasia que poderia chamar, sem medo, de homossexual. Ora, quando um não quer, dois não brigam. Ainda que role uma paquera nos chuveiros comuns—o que é de se esperar, já que pessoas têm sexualidade e desejos —, cabe ao paquerado aceitar ou não aceitar, afinal algum policial militar heterossexual pede licença às mulheres para iniciar suas cantadas quase sempre grosseiras, obscenas e misóginas? Não. Então, por que exigir dos militares homossexuais que eles silenciem sua sexualidade sob pena de expulsão? Do que os machos da PM têm medo? De não resistirem e cederem às cantadas? Quem está seguro de sua orientação sexual não tem medo do outro.

As falas do coronel Carlos Maurício também são reprováveis: 'Ele estava manchando a imagem da polícia em Porto Seguro. Disputava o amor de um soldado com outro tenente'. Ora, por que o amor mancharia a imagem da PM? E o que o coronel tema ver com a vida sexual de seus subordinados? Se o fato de muitos soldados, sargentos e oficiais heterossexuais terem amantes e/ ou segundas famílias às escondidas não interfere no desempenho de suas funções, entâo, por que o fato de um tenente gay amar outro homem o impediria de ser bom militar? Como se vê, é discriminação e homofobia.

Como forma de sociabilidade masculina, a PM, não só a da Bahia, é misógina (trata as mulheres como inferiores a despeito da presença das policiais) e homofóbica. As falas do coronel, o parecer do promotor e o silêncio do governo mostram que a masculinidade se constrói e se afirma publicamente contra a homossexualidade. Contudo, embora a PM proscreva a homossexualidade das relaçóes que prescreve a soldados, sargentos e oficiais há tanto nas polícias quanto no futebol uma espécie de erotismo homossexual generalizado, como expressa bema fantasia contida no parecer do promotor. Muitos 
militares devem ter certo prazer na ideia de que formam um clube fechado de homossexuais enrustidos que gozam às escondidas.

A ordem sexual pede ou manda que se cale acerca da homossexualidade e, assim, condena a mesma à invisibilidade histórica, pois, se você fala que é gay ou lésbica, a ordem sexual - construída pelos heterossexuais por meio de discurso militar, religioso, científico e artístico-cultural - trata de puni-lo com injúrias, ofensas, piadas grosseiras, caricaturas, boicotes profissionais e outras formas de violência.

*Jean Wyllys é colunista do jornal CORREIO. 119 


\section{ANEXO II}

\section{Revista da Globo evita capa com beijo entre sargentos gays do Exército}

A revista semanal "Época", publicada pela editora Globo, cogitou colocar em sua capa a imagem de um beijo gay entre dois militares. Em sua última edição, a revista trouxe a história dos sargentos do Exército Laci Marinho de Araújo e Fernando de Alcântara de Figueiredo, que assumiram sua homossexualidade.
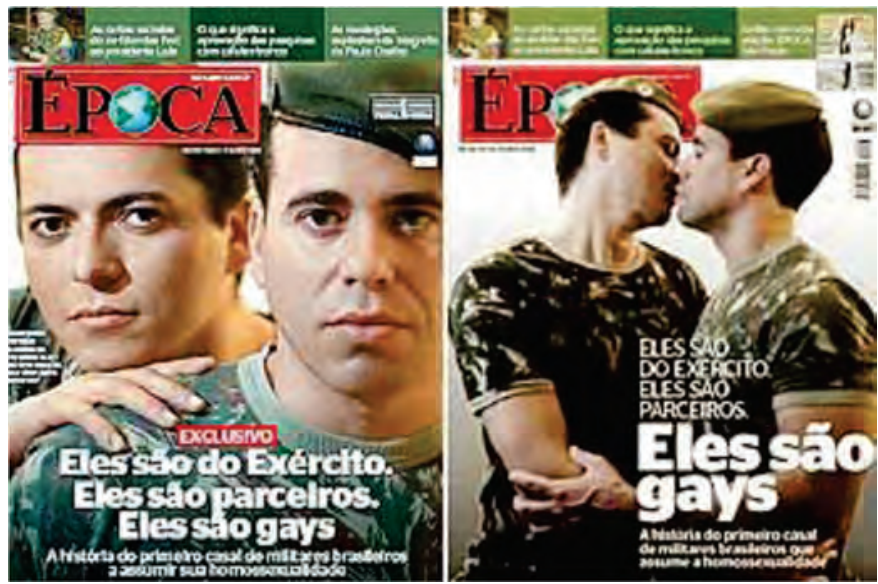

"Época" chegou a considerar a capa (à dir) com o beijo dos sargentos gays, mas optou por versão menos polêmica;

A opção da capa da "Época" mostrava o beijo do casal, na boca. O sargento Araújo foi preso, na madrugada da quarta-feira (4), pelo Exército, acusado de deserção. Ele e o companheiro estavam na sede da Rede TV! em Barueri (Grande SP), onde participaram do programa "SuperPop", de Luciana Gimenez;

A direção da "Época" confirmou que a capa do beijo gay era uma das alternativas.

"A foto [do beijo gay] foi considerada. Normalmente trabalhamos com duas ou três alternativas de capa. Refletimos e optamos por dar a que foi publicada por julgá-la mais adequada", informou Paulo Nogueira, diretor editorial da editora Globo, por e-mail. 
A capa escolbida pela revista mostra apenas Laci com a máo no ombro de Figueiredo. O blog da equipe de criação e design da revista postou as três opçôes de capa - a outra alternativa apenas retratava os rostos próximos dos militares, sugerindo a intenção do beijo.

A exemplo da revista "Época", a TV Globo também evita exibir beijo entre pessoas do mesmo sexo em suas produçôes. Foi o que aconteceu com "Duas Caras”, que terminou no último sábado (31). Aguinaldo Silva, autor da novela das $21 \mathrm{~h}$, escreveu uma cena do beijo entre os personagens Bernardinho (Thiago Mendonça) e Carláo (Lugui Palhares), mas a emissora proibiu o beijo. 